\title{
Soil Microbial Population in Rasomati Forest of Pundibari Range, Cooch Behar, West Bengal, India
}

\author{
Biplov Ch. Sarkar ${ }^{1}$, Amarendra N. Dey ${ }^{1}$, Ayon Roy $^{2}$ and Barun Rai ${ }^{2}$ \\ ${ }^{1}$ Department of Forestry, Faculty of Horticulture, Uttar Banga Krishi Viswavidyalaya, \\ Pundibari, Cooch Behar, West Bengal, India \\ ${ }^{2}$ Department of Plant Pathology, Faculty of Agriculture, Uttar Banga Krishi Viswavidyalaya, \\ Pundibari, Cooch Behar, West Bengal, India \\ *Corresponding author
}

\begin{tabular}{|c|c|}
\hline & A B S T R A C T \\
\hline Keywords & \multirow{4}{*}{$\begin{array}{l}\text { An experiment was carried out in Rasomati forest of Pundibari range of } \\
\text { West Bengal, India in respect to the variation in bacterial and fungal } \\
\text { populations. The mean colony forming unit (cfu) of bacteria was } 6.02 \\
\text { whereas average fungi colony forming unit (cfu) was } 5.31 \text {. It was observed } \\
\text { that Gram -ve bacteria was found higher as compared to Gram +ve. The } \\
\text { genus Aspergillus and Penicillium was recorded highest percentage as per } \\
\text { the counting of colonies. Over all soil were sandy loam to clay loam and } \\
\text { slightly acid in all sites with mean pH } 6.24 \text { and the percentage of organic } \\
\text { carbon was } 1.96 \% \text {. }\end{array}$} \\
\hline $\begin{array}{l}\text { Soil, } \\
\text { Microbial } \\
\text { population, } \\
\text { Forest. }\end{array}$ & \\
\hline Article Info & \\
\hline $\begin{array}{l}\text { Accepted: } \\
\text { 15 March } 2017 \\
\text { Available Online: } \\
10 \text { April } 2017\end{array}$ & \\
\hline
\end{tabular}

\section{Introduction}

Soil microorganisms are vital for the continuous cycling of nutrients and for driving above-ground ecosystems (Van der Heijden et al., 1998; Cairney, 2000; Klironomos et al., 2000; Ovreas, 2000; Kirk et al., 2004). The soil microbe decompose the plant and animal residues entering the soil and convert them into soil organic matter, which influence the physico-chemical and biological properties and creates a complimentary medium for biological reactions and life support in the soil environment (Olson et al., 2000; Das et al., 2013). Soil microorganisms are not only the driving force to carry and transfer the nutrient substrate through biochemical process (Lima et al., 1996; Jorden et al., 1999; Garau et al., 2007) but also play a crucial role in the functional process of the entire ecosystem since they can exert essential effect on the dynamics of multi-directional microbiological processes. Soil microbial enzymatic activity is central to the soil biological processes as it is associated with organic matter breakdown and nutrient cycling which is being mediated by soil microorganism (Karam et al., 2012). That's why the study on microbiological diversity are essential to understand the microbial ecology and other ecosystems (Atlas, 1984). 
A number of works on microbial population and diversity has been carried out in agricultural field but few works have been conducted in forest ecosystem. So, this study deals with the soil bacterial and fungal population and soil physico-chemical properties of the Rasomati forest. Rasomati forest is situated near to river Toorsa basin which comes under Pundibari range of Cooch Behar forest Division of West Bengal. The overall forest is consisting of mixed deciduous tree species under tropical moist deciduous forest (Champion et al., 1968). However, this forest is the home of many important flora and fauna, which are highly vulnerable due to the anthropogenic activities as it is surrounded by many villages. Therefore, the scientific conservation majors need to be taken to conserve this rich biodiversity.

\section{Materials and Methods}

The study was conducted in Rasomati forest located between $26^{\circ} 27^{\prime} 44.0^{\prime \prime} \mathrm{N}$ latitude and $88^{\circ} 19^{\prime} 57.8^{\prime \prime}$ E longitude with an elevation of $66 \mathrm{~m}$ above mean sea level. Rasomati forest comes under Pundibari forest range of Cooch Behar forest Division of West Bengal, at northern fringe of the state in the foothills of sub-Himalayan mountain belts. The detail of the geographical map of the study area is shown in figure 1 .

The climate is moist tropical (Anonymous, 2001). The average minimum and maximum temperature varied from $23.08^{\circ} \mathrm{C}$ during winter (January) to $33.42^{\circ} \mathrm{C}$ during summer (July). On an average the annual rainfall varies from $2000 \mathrm{~mm}$ to $3500 \mathrm{~mm}$, bulk of which is being received during pre-monsoon and monsoon period i.e. May to September. The quantum of precipitation is very low during winter. The relative humidity of the area varies from $55 \%$ to $90 \%$. Consequently, the area is warm and humid except a short spell of winter extending from December to February.

Soil samples were collected from 45 random plots at $(0-10 \mathrm{~cm})$ depth by covering the total area and 9 composite samples were prepared for the further studied during the month of February to March 2016. The sample put in a sterile poly bags and immediately brought into the laboratory. The $\mathrm{pH}$ of the soil was determined by making a soil solution with the help of digital $\mathrm{pH}$ meter and organic carbon was measured by Walkley and Black, 1934. Serial dilution plate method (Parkinson et al., 1971) was followed for the isolation of fungal and bacterial populations. One gram of soil was taken in a $250 \mathrm{~mL}$ conical flask containing $100 \mathrm{~mL}$ of sterilized distilled water to give a 1:100dilutions. It was then diluted to $10^{-4}$ to $10^{-6}$ respectively for fungal and bacterial counts. Bacteria were enumerated using nutrient agar (Difco manual, 1953) and fungi on rose Bengal agar (Martin, 1950). In each case $0.5 \mathrm{ml}$ of the soil suspension was spread onto plates containing $20 \mathrm{ml}$ of the solidified medium and incubated at $28 \pm 1{ }^{\circ} \mathrm{C}$ for 5 days for fungi and at $28 \pm 1^{0} \mathrm{C}$ for 48 hours for bacteria. Three replicate were maintained for each set. The Colony Forming Unit (CFU) per gram soil was calculated on the dry weight basis.

$\mathrm{CFU} / \mathrm{gD}_{\mathrm{w}}$

$=\frac{\text { Number of colony } * \text { dilution factor } * \text { inocollum }}{\text { Dry weight of soil (B) }}$

Where, $D_{\mathrm{w}}=$ Dry weight of the soil $(\mathrm{g})$

Discrete fungal colonies appeared and were identified under the microscope with the help of standard manuals (Gilman, 1995; Barnett and Hunter, 1972). The bacterial isolation was done by morphological character by observing under microscope using gramstaining techniques (Gram, 1884). 


\section{Results and Discussion}

The soil $\mathrm{pH}$ and organic carbon was varied among the sample. The $\mathrm{pH}$ of the soil varied from 5.97 to 6.50 with a mean value of 6.24 whereas the organic carbon contain varied from 1.51 to $2.29 \%$ with an average value of $1.93 \%$. Table 1 revealed that highest colony forming unit (cfu) of bacteria was observed in $\mathrm{G}_{6}$ (6.54) and lowest was in $\mathrm{G}_{3}$ (5.3). The CFU of bacteria was in $\mathrm{G}_{4}$ (6.38) which were statistically at par with $\mathrm{G}_{5}(6.29)$ and $\mathrm{G}_{7}$ (6.29) respectively. The bacterial population in petri plate's indicated that maximum colonies were found as Gram -ve bacteria than Gram +ve. Table 2 and figure 2 described and illustrated the cultural variations in bacterial populations. Similarly, in case of fungi highest and lowest cfu was recorded in $\mathrm{G}_{7}$ (5.88) and $\mathrm{G}_{3}$ (3.77) respectively. The fungal population was significantly at par among the other sample groups.

Among fungi population, genus Aspergillus and Penicillium was identified and recorded highest population whereas other colonies need to be identified. The cultural variations in fungal populations were depicted in table 3 and figure 3. This result indicated that the study area was highly diverse because of the vegetation cover with maximum nutrients. Maximum population or diversity of the genus Penicillium and Aspergillus may be due to their greater rate of spore production and dispersal and partly due to their resistance over extreme environmental conditions. This finding is close agreements with the findings of Schimel (1995); Kayang (2006) and Das et al., (2013).

Table.1 Variations of bacterial cfu ( $\times 105 \mathrm{~g}^{-1}$ soil $)$ and fungal cfu $\left(\times 105 \mathrm{~g}^{-1}\right.$ soil $)$

\begin{tabular}{|c|c|c|}
\hline Group & Bacteria & Fungi \\
\hline $\mathrm{G}_{1}$ & $(5.69) 489778.8$ & $*(5.63) 426579.5$ \\
\hline $\mathrm{G}_{2}$ & $(5.77) 588843.7$ & $*(5.2) 158489$ \\
\hline $\mathrm{G}_{3}$ & $(5.3) 199526.2$ & $(3.77) 5888.437$ \\
\hline $\mathrm{G}_{4}$ & $*(6.38) 2398833$ & $*(5.36) 229086.8$ \\
\hline $\mathrm{G}_{5}$ & $*(6.32) 2089296$ & $*(5.46) 288403.2$ \\
\hline $\mathrm{G}_{6}$ & $(6.54) 3467369$ & $*(5.2) 158489.3$ \\
\hline $\mathrm{G}_{7}$ & $*(6.29) 1949845$ & $*(5.88) 758577.6$ \\
\hline $\mathrm{G}_{8}$ & $(5.94) 870963.6$ & $*(5.69) 489778.8$ \\
\hline $\mathrm{G}_{9}$ & $(6.03) 1071519$ & $*(5.65) 44668.3$ \\
\hline $\mathbf{C . V}(\boldsymbol{\%})$ & $\mathbf{1 . 5}$ & $\mathbf{2 0 . 2 3}$ \\
\hline $\mathbf{C D}(\mathbf{P = 0 . 0 5})$ & $\mathbf{0 . 1 6}$ & $\mathbf{1 . 8 6}$ \\
\hline
\end{tabular}

Parentheses indicate the $\log$ transformed value. Symbol $*$ do not differ significantly. 
Table.2 Cultural variations in bacterial population

Group Variability in cultural characteristics of bacterial population

Moderate single colonies, circular smooth white translucent with raised elevation as

$\mathrm{G}_{1} \quad$ Gram ve- $(70.59 \%)$

Minute whitish single dry circular colony raised elevation gram as Gram ve+ (29.41\%).

Small convex, entire colony yellow pigmentation at edge of petri plate as Gram ve-

$\mathrm{G}_{2} \quad(53.85 \%)$

Filamentous irregular opaque white colonies as Gram ve- (15.38\%)

Moderate round opaque, spreading edge colonies as Gram ve- (30.77\%)

$\mathrm{G}_{3} \quad$ Moderate opaque irregular undulated, lobate colonies as gram ve- (58.82\%)

Tiny circular yellow colony as Gram ve- $(41.18 \%)$

$\mathrm{G}_{4} \quad$ Dull irregular smooth convex whitish cottony growth and single small opaque

filamentous flat white colony as Gram ve+ $(44.55 \%)$

Tiny white pigment round irregular and entire opaque colonies, covering the total surface of petri plate as Gram ve- $(47.27 \%)$

Small irregular and round rhizoids form opaque with yellow pigmentation as Gram ve- $(8.18 \%)$

G5 Pinpoint round small colony and moderate convex translucent colony at the edge of petri plate as Gram ve- (70\%)

Punctiform irregular and round rhizoids form opaque with yellow and black pigmentation small colonies as Gram ve- (30\%)

G6 Small irregular and round rhizoids form opaque with yellow pigmentation as Gram ve- $(42.45 \%)$

Small round irregular form, entire opaque colonies covering the total area of petri plate as Gram ve- $(57.55 \%)$

G7 Moderate round opaque, spreading edge colonies as Gram ve- (39.30\%)

Tiny white pigment round irregular and entire opaque colonies as Gram ve$(60.70 \%)$

G8 Very minute, single circular whitish colonies as Gram ve- $(34.88 \%)$

Moderate round opaque, spreading edge colonies as Gram ve- (46.51\%)

Tiny white pigment round irregular and entire opaque colonies, covering the total surface of petri plate as Gram ve- $(18.60 \%)$

G9 Small convex, entire colony yellow pigmentation at edge of petri plate as Gram ve(76.81\%)

Dry whitish yellow slimy colonies with raised elevation as Gram ve- (23.19\%) 
Fig.1 Google earth map of the study area

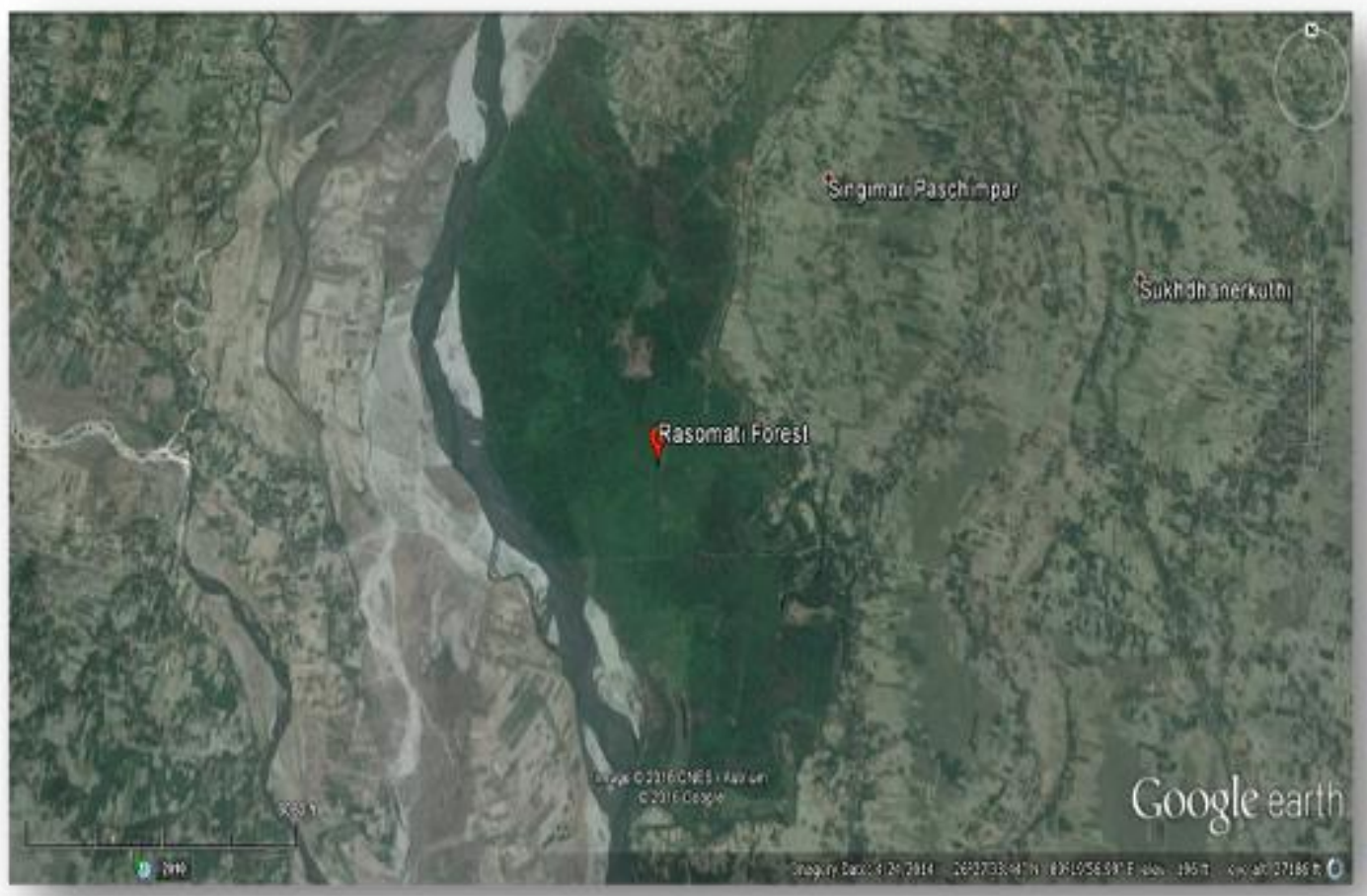

Fig.2 Isolated bacterial culture

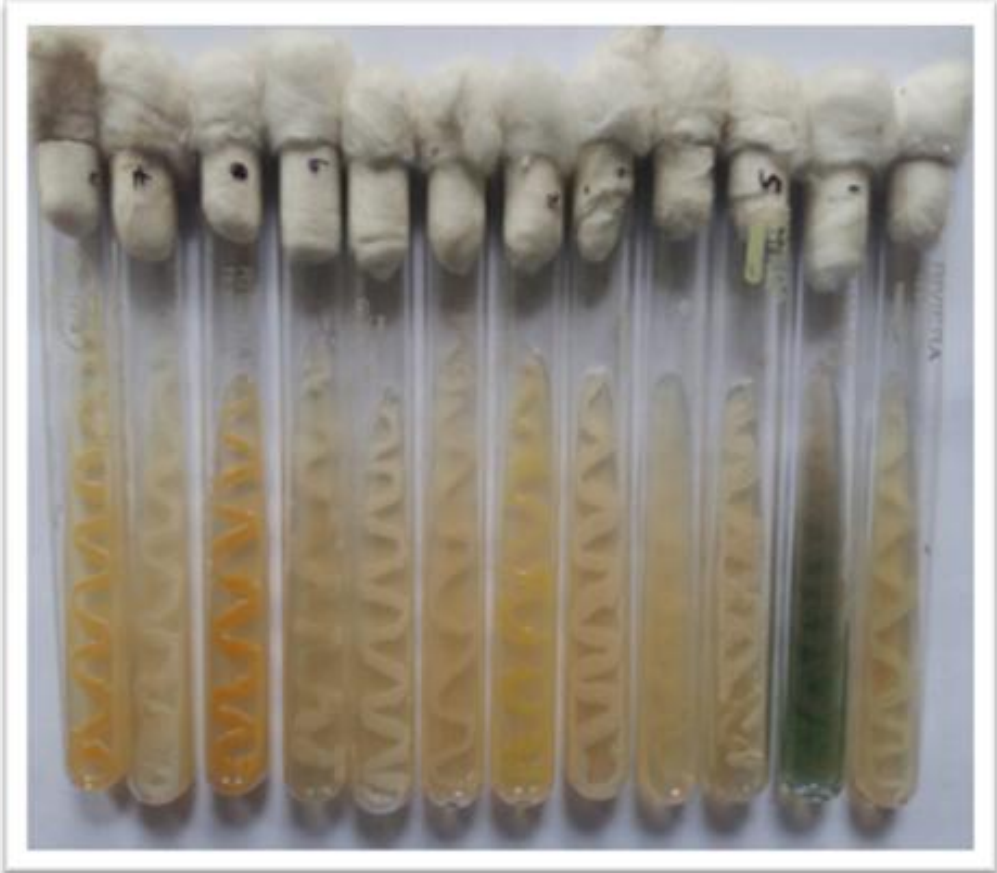


Fig.3 Isolated fungi culture

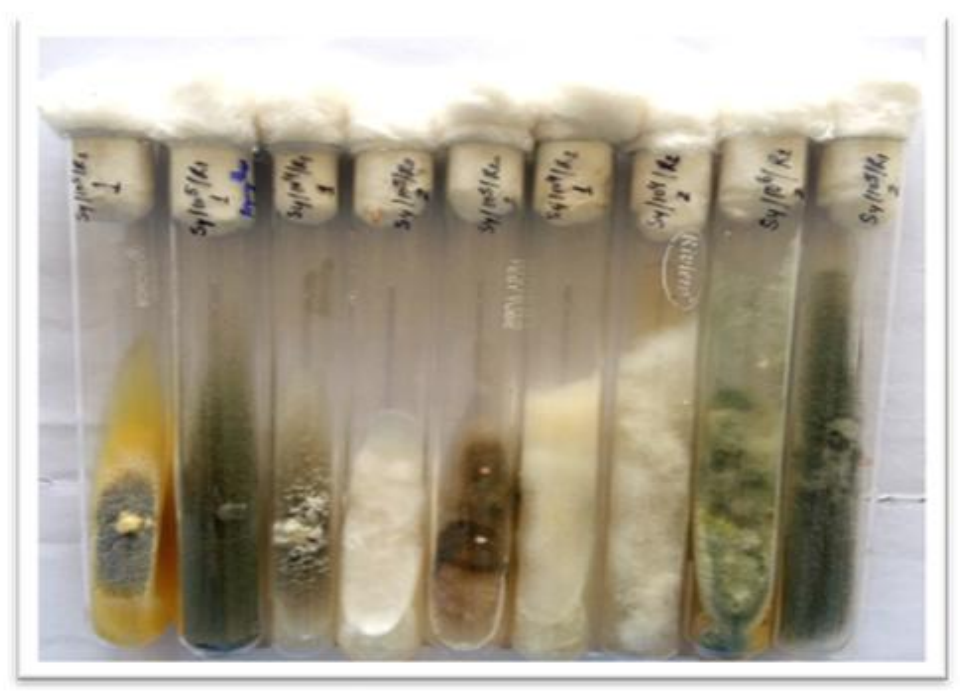

In conclusion, the present study concluded that bacterial and fungi populations in Rasomati forest are influenced by the diverse tree composition and physico-chemical properties of soil. Even, the climatic behaviour and soil nutrients status cannot be completely ignored in this aspect. The preliminary work has been carried out to understand the microbial population for a one season variation. Thus, further more scientific studies are needed to conduct in this area for the species identification and to understand their diversity on seasonal basis.

\section{References}

Anonymous. 2001. $4^{\text {th }}$ working plan for the forests of Cooch Behar district and Jalpaiguri district (part) comprising Cooch Behar forest division and Cooch Behar S.F Division. Volume 1, 2000-01 to 2009-10. Darjeeling: Divisional Forest Officer, Working plans (North) Division, pp 180.

Atlas, R.M. 1984. Diversity of microbial communities, In: Advances in microbial ecology (Eds K.C Marshall).Plenium Press, New york, Vol.7, pp. 1-47.

Barnett, H.L. and Hunter, B.B. 1972. Illustrated Genera of Imperfect Fungi,
Burgess Publishing Company, Minneapolis, Minnesota, USA.

Cairney, J.W.G. 2000. Evolution of mycorrhiza systems, Naturwissenschaften, 87: 467-475.

Das, K., Nath, R. and Azad, P. 2013. Soil microbial diversity of Dibru-Saikhowa biosphere reserve forest of Assam, India, Global J. Sci. Fortier Res. Biol. Sci., 13(3): 1.

Difco Manual. 1953. Difco Laboratories, $9^{\text {th }}$ ed. Inc. Detroit Mich.

Garau, G., Castaldi, P., Santona, L., Deiana, P., and Melis, P. 2007. Influence of red mud, zeolite and lime on heavy metal immobilization, culturable, heterotrophic microbial populations and enzyme activities in a contaminated soil, Geoderma, 142: 47-27.

Gilman, J.C. 1995. A Manual of Soil Fungi, Printwell Publications, Jaipur, India.

Gram, C. 1884. The differential staining of Schizomycetes in tissue sections and dried preparations, Fortschittder Der Med., 2: 185-189.

Jordan, D., Li, F., Jr, F.P., Berry, E.C. and Hubbard V.C. 1999. The effects of forest practices on earthworm populations and soil microbial biomass 
in a hardwood forest in Missouri, Appl. Soil Ecol., 13: 31-38.

Karam, D.S., A. Arifin, O. Radziah, J. Shamshuddin and Majid N.M. 2012. Impact of long-term forest enrichment planting on the biological status of soil in a deforested dipterocarp forest in Perak, Malaysia, Sci. World J., 10: 641346.

Kayang, H. 2006. Soil microbial populatin numbers in sacred grove forest of Meghalaya, Northeast India, Asian J. Microbiol. Biotechnol. Environ. Sci., 8(3): 521-526.

Kirk, J.L., Beadette, L.A., Hart, M., Moutoglis, P., Klironomous, J.N., Lee, H., and Trevors, J.T. 2004. Methods of studying soil microbial diversity, $J$. Microbiol. Methods, 58: 169-188.

Klironomos, J.N., McCune, J., Hart, M., Neville, J. 2000. The influence of arbuscular mycorrhizae on the relationship between plant diversity and productivity, Ecol. Lett., 3: 137-141.

Lima, J.A., Nahas, E. and Gomes, A.C. 1996. Microbial populations and activities in sewage sludge and phosphate fertilizeramended soil, Appl. Soil Ecol., 4: 75-82.

Martin, J.P. 1950. Use of acid rose Bengal and streptomycin in the plate method for estimating soil fungi, Soil Sci., 69: 215-232.

Olson, R.K., Schoeneberger, M.M. and Aschmann, S.G. 2000. An ecological foundation for Temperate Agroforestry. In: North American Agroforestry, An Integrated Science and Practice, Eds. H.
E. Garrett, W. J. Rietveld and R. F. Fisher, Wisconsin, USA: American Society of Agronomy, Madison, pp. 3161.

Ovreas, L. 2000. Population and community level approaches for analysing microbial diversity in natural environments, Ecol. Lett., 3: 236-251.

Pace, N.R. 1997. A molecular view of microbial diversity and the biosphere, Science, 276: 734-740.

Parkinson, P., Gray, T.R.G. and William, S.T. 1971. Methods for studying the ecology of soil microorganisms. Blackwell Scientific Publication Oxford, pp.116.

Schimel, D.S. 2001. Recent patterns and mechanisms of carbon exchange by terrestrial ecosystems, Nature, 414: 169-172.

Van der Heijden, M.G.A., Klironomos, J.N., Ursic, M., Moutoglis, P., StreitwolfEngel, R., Boller, T., Wiemken, A., and Sanders, I.R., 1998. Mycorrhizal fungal diversity determines plant biodiversity, ecosystem variability and productivity, Nature, 396: 69-72.

Waksman, S.A. and Fred, E.B. 1992. A tentative outline of plate method for determining the number of microorganisms in the soil, Soil Sci., 14: 27-28.

Walkley, A. and Black, I.A. 1934. An examination of Degtjareff method for determining soil organic matter and a proposed modification of the chromic acid titration method, Soil Sci., 37: 2937.

\section{How to cite this article:}

Biplov Ch. Sarkar, Amarendra N. Dey, Ayon Roy and Barun Rai. 2017. Soil Microbial Population in Rasomati Forest of Pundibari Range, Cooch Behar, West Bengal, India. Int.J.Curr.Microbiol.App.Sci. 6(4): 1554-1560. doi: https://doi.org/10.20546/ijcmas.2017.604.191 